\title{
ANALISIS STRUKTURAL NOVEL $O$ KARYA EKA KURNIAWAN
}

\author{
Pandu Dian Samaran, Amrizal, dan Bustanuddin Lubis \\ Program Studi Pendidikan Bahasa Indonesia \\ Jurusan Pendidikan Bahasa dan Seni \\ FKIP Universitas Bengkulu \\ pandudian.samaran@gmail.com
}

\begin{abstract}
ABSTRAK
Tujuan penelitian ini untuk mendeskripsikan struktur serta keterkaitan antarunsur dalam Novel $O$ karya Eka Kurniawan. Metode penelitian yang digunakan adalah penelitian kualitatif dengan pendekatan struktural. Data yang dikumpulkan berupa teks yang berkaitan dengan unsur pembangun novel. Sumber data dalam penelitian ini adalah novel $O$ karya Eka Kurniawan. Gramedia Pustaka Utama, cetakan pertama pada tahun 2016 di kota Jakarta. Teknik pengumpulan data menggunakan teknik pustaka. Teknik analisis data, yaitu membuat sinopsis, mendeskripsikan unsur-unsur struktur pembangun yang terdapat dalam novel $O$ karya Eka Kurniawan, menganalisis keterkaitan antar unsur pembangun yang terdapat dalam novel $O$ karya Eka Kurniawan, dan membuat kesimpulan. Hasil penelitian ini berupa (1) Unsur-unsur struktur pembangun novel $O$ karya Eka Kurniawan. Tema yang terdapat dalam novel ini adalah kehidupan seperti lingkaran. Alur yang digunakan dalam novel $O$ adalah alur regresif. Tokoh utamanya adalah O, Entang Kosasih. Sobar, Joni Simbolon, Betalumur, Kirik, Toni Bagong, Dara. Latar tempat dalam novel $O$ adalah Rawa Kalong, bangku, gang-gang kecil permukiman. Latar waktu dalam novel $O$ adalah sore, pagi hari, subuh. Latar sosial dalam novel $O$ adalah latar sosial kelas rendah. Sudut pandang yang digunakan dalam novel $O$ adalah sudut pandang diaan maha tahu. Amanat dalam novel $O$ adalah kehidupan yang terus berputar seperti lingkaran atau seperti huruf $O$. (2) Keterkaitan antar unsur yang terdapat dalam novel $O$ berangkat dari tokoh $O$. Tokoh O mengaitkan semua unsur novel menjadi suatu makna yang utuh. Tokoh utama $\mathrm{O}$ adalah seekor monyet betina yang ingin menjadi manusia, namanya dijadikan judul novel dan dicantumkan dalam cover atau sampul novel.
\end{abstract}

Kata kunci: Novel O, struktural

\begin{abstract}
Abstrack
The purpose of this study is to describe the structure and interrelationship between elements in a novel $O$ by Eka Kurniawan. The research method used is qualitative research with structural approach. Data collected in the form of text relating to elements novel builder. The data source in this study is the novel $O$ by Eka Kurniawan. Gramedia Main Library, the first print in 2016 in the city of Jakarta. Technique data collection using library techniques. Data analysis technique, namely making a synopsis, describe the building structure elements contained in Eka's novel O Kurniawan, analyzed the relationship between building elements found in the novel $O$ by Eka Kurniawan, making conclusions. The results of this study are in the form of (1)
\end{abstract}


structural elements the builder of the novel O by Eka Kurniawan. The theme found in this novel is life like a circle. The plot used in novel $O$ is a regressive plot. Main figure is O, Entang Kosasih. Sobar, Joni Simbolon, Betalumur, Kirik, Toni Bagong, Dara. The setting of the place in the novel $O$ is Rawa Kalong, a bench, small residential alleys. The time setting in novel $O$ is afternoon, morning, dawn. The social setting in novel $O$ is the setting low class social. The viewpoint used in novel $O$ is diaan maha tahu. The message in the novel $O$ is life that continues to spin like a circle or like the letter $O$. (2) The connection between the elements contained in the novel $O$ departs from figure $O$. Figure $O$ associates all elements of the novel into a whole meaning. Figure main $O$ is a female monkey who wants to be human, the name is used as the title novels and included in the cover or cover of the novel.

\section{Keywords: Novel O, Structural}

\section{PENDAHULUAN}

Novel $O$ Karya Eka kurniawan adalah novel yang bercerita tentang seekor monyet yang ingin menjadi manusia. Novel ini memiliki uraian singkat yang berada di sampul belakang novel "Tentang Seekor Monyet yang Ingin Menikah dengan Kaisar Dangdut". Sudah ada dua tokoh yang diketahui sebelum menikmati novel ini lebih jauh. O (seekor monyet) dan Kaisar Dangdut. Keseluruhan novel ini tidak hanya bercerita tentang kedua tokoh itu saja. Namun, ada banyak karakter atau tokoh dengan berbagai watak yang memiliki kisahnya masing-masing dan berkaitan dengan 0 . Memiliki alur (plot) yang rumit dengan latar kehidupan orang-orang menengah ke bawah. Pesan yang tersimpan rapi dalam keseluruhan isi cerita.

Kehadiran tokoh monyet dalam novel ini merupakan sesuatu yang unik. Monyet yang berperilaku seperti manusia dan bahkan ingin menjadi manusia, membuat novel ini memiliki sisi yang menarik. Hewan yang mempunyai perasaan sebagai manusia dan di sisi lain ada manusia yang bertingkah seperti hewan. Sehingga menimbulkan banyak pesan moral atau amanat yang dapat diambil dari tokoh monyet dan tokoh lain yang muncul pada novel tersebut.
Novel $O$ memiliki sampul yang unik, dengan gambar monyet dan huruf " $O$ " yang membuat peneliti dan pembaca tertarik dengan makna pada sampul tersebut sebelum membaca isinya. Hal ini menunjukkan bahwa O mempunyai peran penting dalam setiap unsur-unsur pembangun pada Novel $O$ tersebut dan hal tersebut menjadi salah satu alasan peneliti tertarik menganalisis Novel $O$ menggunakan kajian struktural. Menurut Suwondo (dalam Jabrohim, 2012 : 69), satu konsep dasar yang menjadi ciri khas teori struktural adalah anggapan bahwa di dalam dirinya sendiri karya sastra merupakan suatu struktur yang otonom yang dapat dipahami sebagai suatu kesatuan yang bulat dengan unsur-unsur pembangunnya yang saling berjalinan.

Pendekatan struktural pertama kali dikembangkan oleh kaum Formalis Rusia (1915-1930) (Teeuw, 1984). Latar belakang munculnya pendekatan tersebut adalah untuk membebaskan ilmu sastra dari kungkungan ilmu-ilmu lain, misalnya psikologi, sejarah, dan penelitian kebudayaan. Hal ini karena sebelumnya karya sastra dipahami dalam hubungannya dengan psikologi, sejarah, kebudayaan, masyarakat, serta faktor ekstrinsik lainnya. (Wiyatmi, 2008:89). Analisis struktural pada 
novel $\mathrm{O}$ menggunakan metode penelitian kualitatif. Penelitian kualitatif adalah penelitian yang bermaksud untuk memahami fenomena tentang apa yang dialami subjek penelitian misalnya perilaku, persepsi, motivasi, tindakan dan lain-lain., secara holistik dan dengan cara deskripsi dalam bentuk kata-kata dan bahasa, pada suatu konteks khusus yang alamiah dan dengan memanfaatkan berbagai metode alamiah (Moleong, 2007:6).

Penelitian dengan karya Eka Kurniawan yang menjadi objek penelitian sudah banyak dilakukan, diantaranya berjudul "Struktur dan Pergerakan Penceritaan Fantastik Novel Cantik Itu Luka, Lelaki Harimau, dan Seperti Dendam, Rindu Harus dibayar Tuntas Karya Eka Kurniawan" oleh Yulis Majidatul Choiriah mahasiswa Universitas Airlangga Surabaya pada tahun 2016. Kemudian ada penelitian dengan judul "Psikologis Tokoh Margio dalam Novel Lelaki Harimau karya Eka Kurniawan" diteliti oleh mahasiswa Universitas Airlangga Surabaya, Mega Surya Gemilang pada tahun 2016.

Penelitian ini bertujuan untuk mendeskripsikan struktur serta keterkaitan antar unsur dalam Novel $O$ Karya Eka Kurniawan.

\section{METODE}

Penelitian ini menggunakan metode penelitian kualitatif. Penelitian ini mendeskripsikan unsur intrinsik serta keterkaitan antar unsur dalam Novel $O$ karya Eka Kurniawan.

Pendekatan yang digunakan adalah pendekatan struktural. Langkah kerja structural yang perlu dilakukan adalah sebagai berikut:

1. Membangun teori struktur sesuai dengan genre yang di teliti.

2. Melakukan pembacaan secara cermat, mencatat unsur-unsur struktur yang terkandung dalam bacaan itu.

3. Menganalisis unsur tema.
4. Menganalisis penokohan, alur, latar (setting), sudut pandang dan amanat.

5. Menghubungkan unsur-unsur struktur pembangun untuk mewujudkan kepaduan makna struktur

6. Menafsirkan keterkaitan antar unsur secara cermat (Endraswara, 2008:52).

Teknik pengumpulan data menggunakan teknik pustaka, yaitu dengan menggunakan sumber-sumber tertulis. Data yang diperoleh dalam penelitian kemudian dideskripsikan. Langkah-langkah analisis data dalam penelitian ini adalah sebagai berikut:

1. Membuat sinopsis.

2. Mendeskripsikan unsur-unsur struktur pembangun yang terdapat dalam novel O karya Eka Kurniawan.

3. Menganalisis keterkaitan antar unsur pembangun yang terdapat dalam novel O karya Eka Kurniawan.

4. Membuat kesimpulan.

\section{HASIL PENELITIAN DAN PEMBAHASAN}

Berdasarkan hasil analisis struktural yang terdapat dalam penelitian, ditemukan hasil sebagai berikut:

\section{Unsur-unsur struktur pembangun dalam novel $O$}

Suatu karya sastra dibangun oleh unsur-unsur pembangun yang saling berkaitan, sehingga menjadi karya yang utuh. Unsur-unsur struktur pembangun dalam novel $O$ akan dideskripsikan melalui penjelasan berikut.

\section{a. Tema}

Tema fiksi umumnya diklasifikasikan menjadi lima jenis yakni tema physical'jasmaniah'. Organic'moral, social'sosial'. Egoic'egoik', dan divine'ketuhanan'. (Sayuti, 2000 : 193). Novel $O$ memiliki 3 jenis tema, yaitu tema jasmaniah (phyhical), tema egoik (egoic) dan tema ketuhanan (divine).Tema 
jasmaniah tentang kisah percintaan $\mathrm{O}$ dan Entang Kosasih. Kemudian tema egoik, merupakan tema yang menyangkut reaksireaksi pribadi yang pada umumnya menentang pengaruh sosial. Tema egoik dalam novel ini adalah tentang perjuangan monyet yang ingin menjadi manusia. Beberapa tokoh monyet dalam cerita menolak untuk hidup selamanya menjadi monyet, hal ini berarti mereka menolak untuk hidup seperti monyet pada umumnya. Tema ketuhanan atau divine adalah kehidupan yang seperti lingkaran.

\section{b. Alur atau plot}

Dari segi penyusunan peristiwa, alur dalam Novel $O$ Karya Eka Kurniawan adalah alur regresif karena peristiwa-peristiwa yang disusun dalam novel ini cenderung acak. Di dalam cerita ini juga banyak terdapat peristiwa sorot-balik dengan teknik mengenang masa lalu tokoh.

Dalam bagian Pengenalan situasi cerita (exposition), pengarang memperkenalkan para tokoh serta menata adegan dan hubungan antartokoh. Pengenalan situasi cerita dalam novel $O$ diawali dengan kehidupan monyet-monyet di Rawa Kalong dan kisah cinta antara dua ekor monyet, O dan Entang Kosasih. Bagian pengungkapan peristiwa (complication) disajikan peristiwa awal yang menimbulkan berbagai masalah, pertentangan, ataupun kesukaran-kesukaran bagi para tokohnya. Pengungkapan peristiwa dimulai dengan pernyataan Entang Kosasih untuk mengikuti jejak Armo Gundul yang berarti ia ingin menjadi manusia. Berikutnya menuju pada adanya konflik (rising action) Terjadi peningkatan perhatian kegembiraan, kehebohan, ataupun keterlibatan berbagai situasi yang menyebabkan bertambahnya kesukaran tokoh. Peristiwa menuju pada adalah saat Entang Kosasih membunuh seorang polisi yang bernama Joni Simbolon. Ini adalah peristiwa awal yang akan menjadi sebab Entang Kosasih berubah menjadi manusia.

Puncak konflik (turning point), bagian ini disebut juga sebagai klimaks. Konflik dalam Novel $O$ terjadi saat $O$ bertemu dengan Entang Kosasih. Namun Kaisar Dangdut (Entang Kosasih yang telah menjadi manusia) tidak mengenal $O$. peristiwa itu membuat O kecewa. Konflik berikutnya adalah matinya $O$ sebagai seekor monyet. Karena kecewa lantaran Entang Kosasih alias Kaisar Dangdut tak mengenalinya. $\mathrm{O}$ jadi tak bersemangat dalam kesehariannya. Kemudian $\mathrm{O}$ mati karena diserang oleh seekor anjing galak. Penyelesaian (ending) cerita saat pertemuan antara O dan Entang Kosasih. Mereka akhirnya bisa mewujudkan keinginan untuk menjadi manusia dan bertemu untuk yang pertama kalinya sebagai sosok manusia. Peristiwa pertemuan mereka memang tak dijelaskan secara terperinci oleh pengarang, 0 dan Entang Kosasih membuat janji bertemu di taman.

\section{c. Penokohan}

Novel $O$ memiliki tokoh-tokoh yang digambarkan secara jelas yaitu O, Entang Kosasih, Sobar, Joni Simbolon, Betalumur, Kirik, Toni Bagong, Dara, Revolver, Ma Kungkung, Mat Angin, Kaleng Sarden, Rini Juwita, Marko, Mimi Jamilah, Jarwo Edan, Rudi Gudel, Syekh Asyhadie, Siti, Kiai Sobirin, Manikmaya dan Boboh.

\section{d. Latar atau setting}

Latar tempat dalam novel $O$ adalah Rawa Kalong, bangku, gang-gang kecil permukiman, rumah toko, rel kereta api, swalayan, lorong-lorong kecil, gedung rongsok, timur Jakarta, gang kecil, mushala, surau, rumah sakit dan taman kanak-kanak. Latar waktu yang terdapat dalam novel $O$ adalah sore, pagi hari, subuh, dinihari, menjelang pagi, siang hari dan malam hari. 
Latar sosial yang terdapat dalam novel $O$ adalah latar sosial kelas rendah antara lain kawasan kriminal, terminal bus, permukiman kecil di pinggir jalan tol dan perkampungan pencuri.

\section{e. Sudut pandang atau point of view}

Sudut pandang yang digunakan dalam novel $O$ adalah sudut pandang diaan maha tahu. Eka Kurniawan sebagai pengarang novel $O$, bertindak sebagai pengamat sekaligus narator yang menyampaikan peristiwa yang terjadi di antara tokoh.

Penyampaian cerita oleh pengarang sebagai orang ketiga yang berada di luar cerita. Pengarang menggunakan kata ia, dia atau nama tokoh. Pengarang tidak memegang peranan apa pun. Pengarang hanya menjelaskan hal-hal tentang tokoh dan peristiwa yang dialaminya. Eka Kurniawan sebagai pengarang novel $O$, bertindak sebagai pengamat sekaligus narator yang menyampaikan peristiwa yang terjadi di antara tokoh-tokoh di dalam cerita.

\section{f. Amanat}

Novel O memiliki banyak amanat atau pesan yang ingin disampaikan oleh pengarangnya yaitu Eka Kurniawan. Beberapa amanat yang hendak disampaikan pengarang di dalam novel $O$ adalah (1) bahwa kita harus beriman kepada kitab suci Allah sebagai pedoman hidup, (2) di antara banyaknya manusia yang jahat masih ada manusia yang baik, (3) jangan mencari rezeki dengan cara yang haram, (4) tanpa masa lalu, kita tak akan punya masa depan dan (5) pentingnya pendidikan untuk kehidupan yang lebih baik.

\section{Keterkaitan Antar Unsur dalam Novel 0 Karya Eka Kurniawan}

Unsur-unsur pembangun dalam novel $O$ saling berkaian dan menjadikan suatu karya yang utuh. Keterkaitan antara tema dan alur, novel $O$ memiliki tema perjuangan monyet yang ingin menjadi manusia. Kaitannya dengan alur adalah tema tersebut disampaikan melalui urutanurutan peristiwa yang ada dalam cerita. Keterkaitan antara tema dan tokoh, tema dalam novel $O$ berkaitan erat dengan tokoh-tokoh yang ada di dalamnya. Tokohtokoh yang berperan penting dalam penafsiran tema dalam novel ini adalah $O$ dan Entang Kosasih. Keterkaitan antara alur dan tokoh dalam novel $O$. Pada novel $O$, keterkaitan antara alur dan tokoh sangat erat. Kemunculan para tokoh dalam novel disampaikan melalui alur. Alur juga bertugas menata kejadian-kejadian dan hubungan antar tokoh.

Pada novel $O$ kaitan alur dan latar mempunyai peranan penting. Karena telah dijelaskan di atas, bahwa latar adalah dasar terjadinya peristiwa dalam alur cerita. Latar tempat merupakan tempat terjadinya peristiwa, latar waktu merupakan kapan terjadinya peristiwa. Keterkaitan antara tokoh dan latar pada novel $O$ tampak begitu jelas. O sebagai tokoh utama yang ingin menjadi manusia. Menjadikan sirkus topeng monyet sebagai tempat mempelajari gerak-gerik manusia. Keterkaitan antara tokoh dan amanat. Amanat pada novel $O$ memiliki kaitan dengan tokoh. Seperti salah satu amanat yang terdapat pada novel $O$, yaitu pentingnya beriman kepada kitab suci Allah sebagai pedoman hidup. Amanat tersebut disampaikan oleh pengarang melalui tokoh Syekh Asyhadie.

Keterkaitan antara sudut pandang dan tokoh. Sudut pandang diaan maha tahu yang digunakan pengarang dalam novel $O$ membuat pengarang bebas menceritakan apapun kejadian yang dialami antara tokoh-tokoh di dalam cerita yang dibuatnya. Keterkaitan antara sudut pandang dan amanat. Sudut pandang diaan maha tahu pada novel $O$ meletakkan pengarang sebagai narator yang 
menjelaskan peristiwa, tempat, suasana dan pikiran pelaku cerita. Posisi pengarang sebagai pengamat dan narator di luar cerita, dapat memberi pengarang kuasa penuh untuk menyisipkan amanat pada unsur mana pun yang dikehendakinya.

Keterkaitan antar unsur yang terdapat dalam novel $O$ berangkat dari tokoh $O$. Tokoh $\mathrm{O}$ dalam novel ini mengaitkan semua aspek atau semua unsur novel menjadi suatu makna yang utuh. O berada pada setiap unsur struktur pembangun novel. 0 sebagai tokoh utama dalam cerita, tema dan amanat yang disampaikan melalui peristiwa dan juga dari nama tokoh $\mathrm{O}$. Latar Rawa Kalong yang menjadi tempat tinggal $O$ dan tempat dimana $O$ mengetahui tentang legenda monyet yang menjadi manusia sekaligus tempat yang strategis untuk mempelajari tingkah laku manusia, karena Rawa Kalong adalah daerah hutan dan rawa yang berada dekat pemukiman manusia. $\mathrm{O}$ adalah seekor monyet betina yang ingin menjadi manusia dan namanya dijadikan judul novel dan dicantumkan dalam cover atau sampul novel.

Pengarang menyimbolkan huruf $\mathrm{O}$ atau nama dari tokoh $O$ sebagai lingkaran kehidupan. Sesuai dengan tokoh O yang ingin dilahirkan kembali (Reinkarnasi) menjadi manusia dengan mengalami berbagai macam peristiwa pahit demi mewujudkan keinginannya untuk menjadi manusia dan bahagia. Begitu juga dengan beberapa tokoh lain dalam peristiwa yang terdapat pada novel ini yang ingin merasakan perputaran kehidupan seperti Entang Kosasih dan burung kakak tua yang juga ingin menjadi manusia. Dara dan Sobar yang akhirnya berubah menjadi ikan, betalumur menjadi babi. Beberapa peristiwa penting dalam novel $O$ juga menyangkut soal Tokoh yang ingin merasakan putaran posisi kehidupan (Hewan-manusia, manusia-hewan, jahatbaik)
Secara keseluruhan cerita dalam novel O menggambarkan hidup yang seperti lingkaran, seperti huruf $O$. Tema yang di angkat oleh Novel $\mathrm{O}$ tentang lingkaran kehidupan yang tak ada habisnya. Bahwa manusia yang hidup pasti mati dan akan ada manusia yang lahir kembali, atau yang sedih akan bahagia dan yang bahagia akan merasakan sedih. Lingkaran hidup yang ingin disampaikan oleh pengarang disimbolkan juga dengan huruf $\mathrm{O}$ dan nama tokoh O dalam novel.

Latar Rawakalong yang diangkat di dalam novel, merupakan tempat tinggal $O$. Rawakalong adalah suatu daerah hutan dan rawa di pinggiran kota. Di rawa kalong terdapat segerombolan monyet yang tinggal berdampingan dengan manusia, karena sering bersinggungan dengan manusia, monyet di rawakalong mulai mahir meniru gaya hidup manusia, Terlebih Entang Kosasih dan $\mathrm{O}$ yang ingin menjadi manusia. Menurut peneliti ini adalah alasan awal Entang dan Kosasih ingin menjadi manusia, didukung dengan legenda di kalangan para monyet bahwa dahulu ada seekor monyet yang berhasil menjadi manusia.

\section{PENUTUP}

\section{Kesimpulan}

Suatu karya sastra bisa dikatakan utuh karena terdapat unsur-unsur pembangun yang saling berkaitan di dalamnya. Unsurunsur pembangun dalam novel $O$ saling berkaitan dan menjadikan suatu karya yang utuh.

Dari analisis Struktural Novel O, dapat disimpulkan bahwa Unsur-unsur pembangun dalam novel $O$ karya Eka Kurniawan saling berkaitan dengan adanya tokoh $\mathrm{O}$ dan simbol dari nama $\mathrm{O}$ tersebut, sehingga menjadi suatu makna yang utuh. Bahwa kehidupan akan terus berputar seperti lingkaran atau seperti huruf 0 . 0 merupakan tokoh utama dalam cerita yaitu seekor monyet betina yang ingin menjadi 
manusia dan namanya dijadikan judul novel dan dicantumkan dalam cover atau sampul novel. Pengarang menyimbolkan huruf $O$ atau nama dari tokoh $\mathrm{O}$ sebagai lingkaran kehidupan yang menjadi inti cerita dalam novel $\mathrm{O}$.

\section{Saran}

Penulis menyarankan kepada peneliti selanjutnya untuk melanjutkan analisis yang lebih mendalam menggunakan pendekatan lain. Karena dalam penelitian ini peneliti hanya membahas tentang unsur pembangun dan keterkaitan antar unsur pembangun novel $O$. Dari hasil temuan penulis, peneliti selanjutnya dapat menggunakan pendekatan mimetic karena di dalam novel $O$ terdapat banyak simbol yang digunakan. Penulis juga menyarankan kepada peneliti selanjutnya yang akan meneliti novel O karya Eka Kurniawan dapat menggunakan penelitian ini sebagai referensi penelitian.

\section{DAFTAR PUSTAKA}

Endraswara, Suwardi. 2008. Metodologi Penelitian Sastra. Yogyakarta: MedPress (Anggota IKAPI).

Jabrohim. 2012. Teori Penelitian Sastra. Yogyakarta: Pustaka Pelajar.

Kurniawan, Eka. 2016. O. Jakarta: Gramedia Pustaka Utama.

Moleong, Lexy J. 2007. Metodologi Penelitian Kualitatif Edisi Revisi. Bandung: PT Remaja Rosdakarya.

Sayuti, Suminto A. 2000. Berkenalan dengan Prosa Fiksi. Yogyakarta: Gama Media.

Wiyatmi. 2008. Pengantar Kajian Sastra. Yogyakarta: Pustaka. 